\title{
A Critical Discourse Study of Chinese Professors' Image Construction in Microblogging Discourse
}

\author{
Weiwei Mao \\ School of Foreign Language, Dalian University of Technology, Dalian, China
}

\begin{abstract}
With the aim of elaborating what and how Chinese professors' identities are constructed in microblogging discourse, through high-frequency words, collocates and concordance lines, the present study analyzes the ideologies, the academic and moral image of professor behind the collected microblogging data posted on Sina Weibo with topic of "'Mistress Gate' in Fudan University". The results suggest that: (1) Under the new media, Weibo, network catchwords are growing popular and tucao (revealing the inside story) is full of violence. (2) Although most of the netizens hold decent ethics and values, they go emotional easily. (3) A series of negative cases in the media have already made "professor" who usually has a relatively decent social status have a negative connotation.
\end{abstract}

Index Terms — critical discourse studies, corpus, Chinese professors' image, microblogging discourse

\section{INTRODUCTION}

For a long time, teachers have a double responsibility of teaching and cultivating students, whose social image attracts the focus from public, students and teachers themselves. There has been a tradition called "respecting teachers and valuing education" in Chinese society where publics show great respected attitude to teachers social group. However, Xu Chong, a vice professor from Fudan University, China, attracts a hot debate on the Internet on September 10,2015 because of his infidelity within marriage, which has arisen public's query to the personality of university teachers. The corpus-assisted critical discourse analysis is conducted to analyze professor's image in the Microblogging discourse constructed by Chinese netizens. The study reveals social ideology in the Weibo assessment to university teachers through this case, and rethinks how professors, the representation of university teachers, intensify the building of their own personality and quality.

University teachers refers to the social group trained professionally and mastering the specialized knowledge, who takes imparting knowledge and educating people, as well as knowledge creation as occupation with strong feeling of social responsibility; professors are the representation of university teachers. Sociology, communication sciences and higher pedagogy are the main research fields of university teachers' image construction. In social psychology and communication science, Wang (2007) applies the rewriting of "media representation" to "positive" stereotype to analyze the news about university teachers in mass media, and the results show that university teachers with positive stereotype are more easily rewritten by "media representation", additionally, the communication rules that mass media should followed in the process of rewriting the stereotype was proposed. Ban (2007) raises the basic idea of improving teachers' moral image in media, which aims at the phenomenon that teachers are represented with opposite moral images in media, sanctification and demonization. Wen and Xu (2014) analyzes university teachers' identity meaning, professionalism and distinctiveness from the view of sociology and higher pedagogy. On the whole, university teachers' image study mainly focuses on qualitative research, and lacks the support of large number of language data so it may be less persuasive for the research. The corpus-assisted critical discourse analysis is conducted to analyze professor's image construction in the corpus. Aiming at the large language data, corpus linguistics employs the bottom-up and datadriven induction method with the help of corpus and computer software. This kind of research method can make the qualitative study in critical discourse analysis more correct and credible because it reveals the language using change through the combination of quantitative and qualitative analysis.

Weibo, an emerging microblogging website in China, allows its users to post short messages of up to 140 characters or pictures via client-side such as WEB or WAP and to follow the information that they are interested in. Weibo enjoys a higher popularity than other forms of SNS in China. China has been in "era of microblogging" since 2010. According to the report released by China Internet Network Information Center (CNNIC), by June of 2015, there were reportedly 204 million Weibo users in China in which 69.4\% of them are from Sina Microblog. Users whose age is between 32year-old and 51-year-old are the core strengths which influence public opinions on the network. Besides the large number of users, the specialty of Weibo also lies in the following aspects: the convenient posting way, the immediate and expedite communication mode, and the few entry conditions. Despite starting life as a Twitter clone, Weibo has added a number of distinct features to attract Chinese tastes. Weibo platform combined with radio, video and text makes various information presented on the network through diversified communication symbols. As a result, the real situation of the cases is recovered in a large degree, which makes more users believe the truth of the information communicated in Weibo. However, the comments in Weibo posted by netizens lack the depth in traditional media and have the 
characteristics of fragmentization, grassroot and pan-entertainment. But it is these in-authoritative comments that can reflect people's ideology in a country. Due to above distinctive features, Weibo has aroused wide attention of academic scholars from a wide range of disciplines in social sciences.

\section{LITERATURE REVIEW}

\section{A. Critical Discourse Analysis}

Fairclough (2009) holds that discourses are the semiotic methods that construe physical world, social world and mental world, which can be identified with social actors from different groups in different positions or perspectives. Discourse analysis aims at studying the relationship between language and society and revealing the deep problems and the true underlying meanings behind the texts. Critical Discourse Analysis (CDA) is a subject of discourse analysis, which focuses on the power and inequality in language (Blommaert \& Bulcaen, 2000). It originates from the critical linguistics proposed in Fowler and Kress's Language and Control in 1979. With problems as the research orientation, CDA focuses on the relationship between discourse, power and ideology (Blommaert, 2005), and the revealing of control, discrimination and power implied in the language (Wodak, 1995). Speaking more correctly, it studies the real social interactive cases presented in the form of language so it can influence society situation and social reform. In CDA, discourse practice as a important part of social practice constructs meaning when constructing social, politics and cultural reality(Khosravinik, 2014 ); power can influence the formation of social reality and identity, and can maintain and reconstruct the power relations of different social groups at the same time; ideology as the basis of discourse practice and social practice is the relatively stabilized beliefs and values shared by social group, which exists in people's language and practice, and influences the way people deal with social practice and discourse practice. The research themes in CDA mainly include political discourse, ideology, racial discrimination, economics discourse, advertisements and peddling culture, media languages, gender, institution discourse, education and so on. There are eight fundamental principles in CDA: (1) CDA mainly focuses on social problems; (2) Power relations are discursive; (3) Discourse constructs society and culture; (4) Discourse reflects ideology in depth; (5) Discourse is historical; (6) Discourse and society are mediated; (7) Discursive analysis has the characteristics of interpretation and explanation; (8) Discourse is the representation of social actions (Fairclough \& Wodak, 1997).

A three-tiered framework is a common research frame in CDA and was proposed by Fairclough, which consists of the analysis of text, discursive practice and sociocultural practice at micro level, meso level and macro level (Fairclough, 1992). That is to say, each discursive events can be explained from three levels: at the micro level, the text can be in spoken or written form, which mainly analyzes its grammatical resources and language structures; at the meso level, it is to interpret how texts are produced, consumed, and reproduced; at the macro level, it is to explain the reason and the way that social practices influence and constitute the text and discourse construction. Textual analysis at the micro level is related to Halliday's systemic functional grammar and the analysis of ideational, interpersonal, and textual function. Transitivity and types of verbs are included in the analysis of ideational functions; The interpersonal functions analyze the social relations among social participants, which mainly analyzes the mood and the modality; The text structure are analyzed in textual functions. The analysis of discursive practice at the meso level is related to how discourses are produced, interpreted, and reproduced. It is concerned with the way texts are interpreted and reproduced. Sociocultural practice at the macro level involves the power in interdiscursivity and hegemony, and it mainly analyzes the social factors influencing the above two levels. Since CDA was proposed, awareness has been increasing because of its expansive cross-disciplinary range. However, texts in CDA is charged in a cherry-picked way, which results in the problem, such as lacking of representation, objectiveness and systematicness.

\section{B. Corpus-assisted Critical Discourse Analysis}

As a approach combined with qualitative and quantitative analysis, corpus linguistics emphasizes that data volumes needs to be selected from the real situation (McEnery \& Wilson, 2001) and computer software is used to process these language data. It's a supplement to the qualitative study of critical discourse analysis. Recent years there are more and more scholars attempting to combine corpus linguistics with CDA abroad or at home (Baker P. 2006; Baker P. \& Levon E. 2015), which can testify that corpus-assisted critical discourse analysis can deal with the lack of language data in CDA. Hence, there are three advantages for this method: (1) the results based on a large body of electronically coded text can be more reliable; (2) corpus linguistics can help to avoid that data is selected casually or just the related ones because they are suitable for proving the preconceived assumption. (3) the results of corpus is generated in the pattern of frequency so it can deal with the discourse occurring in societies normally. With the approach of 'bottom-up' or datadriven, corpus linguistics analyzes the lexical patterns and grammar structures based on the concordance lines and collocates which can be processed by computer software. Therefore, the salient language features can be elaborated and the underlying meanings of discourses can be analyzed. Although corpus-assisted critical discourse analysis have been studied extensively, the data resources are still limited in traditional media and the study of the data in digital new media is rarely involved.

\section{CASE SELECTION}


On Sep.10th of 2015, a bill of accuse with 8,000 Chinese characters about infidelity within marriage, written by Ms. Sheng, the wife of $\mathrm{Xu}$ Chong who is a vice professor in department of history of Fudan University, appeared on the Internet and was spread rapidly on the Internet forum of China, such as Tianya, Douban, the BBS of Fudan University, Tsinghua University and so on. Henceforth, a family dispute changed into a public event in a short time. On Sep. 13th, in order to confute his wife's accuse, Xu responded with a thirteen-page of PDF file written by the format of academic paper, which attracted wide attention throughout Chinese netizens. On Sep. 16th, Toutiao News, the official Weibo of Sina News, posted a news with the headline of "A Vice Professor of Fudan University Delivered a Thirteen-page Statement to Respond His Fornication with a Single Female Teacher". As soon as the news was released, it attracts no less than 1,100 pieces of comments from Weibo netizens. This media event was under heated debate quickly. Therefore it is appropriate for analyzing discourse analysis of professors' image construction by using critical discourse analysis.

The term "Fudan Professor" was treated as the search word on Sina Weibo to collect Weibo related to "'Mistress Gate' of Fudan University". Finally, the microblogs released by Toutiao News are selected as the context which contains 1,100 pieces of comments with a total number of 39,092 characters.

\section{RESEARCH QUESTIONS}

Based on the three-tiered framework proposed by Fairclough, this study attempts to achieve the following research objectives:

(1) What and how do microblogging discourse producers construct Chinese professor images in particular texts? (micro-level)

(2) Who is involved in the discursive practices and in what role? (meso-level)

(3) What social factors impact on the text and on discourse practice? (macro-level)

\section{RESEARCH DESIGN}

Corpus-assisted critical discourse analysis is used to conduct professors' image construction in Weibo text. Meanwhile, social ideology reflected in Weibo comments of this event will be analyzed. Netizens' comments of "'Mistress Gate' of Fudan University" on Toutiao News is collected and processed by the software of Antconc3.4.3, which generated the word frequency lists, collocates tables and concordances of the corpus. The language structure and its underlying meaning will be identified. As a result, language features that netizens present in the comments of the vice professor in the event, and the ideological issues about social ethics will be analyzed scientifically and quantitatively. The linguistic features of netizens' comments on the vice Professor Xu are to be discussed at the microlevel of discourse. Subsequently, the discourse practices presented by the text will be analyzed at the meso level; the social factors influenced the linguistic way in constructing professors' image will be analyzed at the macro level. In the aspect of word frequency lists, notional words with high frequency in the corpus are made according to their frequency rank in the lists and they can reflect social phenomenon. For the collocates, 28 notional collocates of "professors" ("教 授") are made according to their strength of collocation. For the concordance lines, 7 pieces of concordance regarding "教授" ("professors") as the search term are chosen in the research.

\section{ANALYSIS AND DISCUSSION}

In the microblogging environment, netizens' comment amount of a certain microblogging event can reflect its influences in the society. In the "Fudan Mistress" event, microblogs issued by Sina's "Toutiao News" has attracted 1,100 pieces of comments from netizens. The number of characters is 39,092 so it is sufficient to be used as a corpus for the analysis of this event.

\section{A. The Analysis of High-frequency Words in the Corpus}

Part of the high-frequency words ranked in top 100 (Table I ) is generated by the software of AntConc3.4.3. They are classified into three categories based on nouns, verbs, adjectives. 
TABLE I

PART OF THE HIGH- FREQUENCY WORDS RANKED IN 100

\begin{tabular}{|l|l|l|l|l|l|}
\hline Nouns & Freq. & Verbs & Freq. & Adjectives & Freq. \\
\hline 复旦(Fudan) & 136 & 是(is) & 257 & 多(many) \\
\hline 通奸(fornication) & 78 & 有(have) & 235 & 错(wrong) \\
\hline 教授(professor) & 70 & 出轨(commit the infidelity) & 211 & 恶心(disgusted) & 27 \\
\hline 老师(teacher) & 56 & 离婚(divorce) & 116 & 可怕(awful) \\
\hline 大学(college) & 53 & 没有(no) & 67 & 贱(bitch) \\
\hline 孩子(child) & 52 & 不是(not) & 64 & 不好(not good) & 12 \\
\hline 婚姻(marriage) & 41 & 微笑(smile) & 34 & 痛苦(pain) \\
\hline 叫兽(Jiaoshou) & 33 & 不能(cannot) & 33 & 有理(right) \\
\hline 责任(responsibility) & 29 & 呵呵(hehe) & 33 & & 11 \\
\hline 道德(morality) & 28 & 结婚(marry) & 28 & & 10 \\
\hline 哺乳期(breastfeeding period) & 27 & 分居(separate) & 25 & & \\
\hline 高知(senior intellectuals) & 18 & 应该(should) & 21 & & \\
\hline 败类(scum of a community) & 14 & 闹(quarrel) & 15 & & \\
\hline 借口(excuse) & 12 & 希望(hope) & 13 & & \\
\hline 历史系(Department of history) & 10 & 狡辩(quibble) & 13 & & \\
\hline 学历(education background) & 10 & 需要(need) & 12 & & \\
\hline 教育(education) & 10 & 破裂(break up) & 11 & 11 & \\
\hline 知识(knowledge) & 10 & 骂(scold) & & \\
\hline
\end{tabular}

Among the high-frequency nouns, "fornication", "breastfeeding period", "department of history" etc. reveal the themes of netizens' comments; What's more, "college", "responsibility", "senior intellectuals", "education" etc. show that netizens rethink the issue of Chinese higher education and the moral qualities of senior intellectuals with high academic degree in China. Among the high-frequency verbs, 8 verbs are the process of material action: "commit the infidelity", "divorce", "marry", "separate", "quarrel", "quibble", "scold", "break up", which is used to describe the behaviors of actors; 2 verbs express the verbal process: "smile", "hehe", which shows the mock and the banter expressed by netizens to the event; 2 verbs are related to the relational process: "is" and "not", which describes the behavioral features of actors; as well as the 3 mental processes: "should", "hope", "need", which reflects that netizens pay attention to the case and try to place themselves in the live situation. Among the high-frequency adjectives, "disgusted", "bitch" etc. reveal netizens' negative attitude to the event. They denounce and blame Xu's infidelity.

With the analysis of the high-frequency words, it can be found that the corpus is filled with netizens' negative attitudes to Xu's infidelity. Most netizens think that professors are people who are senior intellectuals with higher social esteem. However, Xu's behavior has seriously damaged the social status of professors. And part of netizens even hold that this case also reflects education problem in China. They believe that Chinese senior intellectuals should be the person with capability and integrity; and teachers should also be the model of academy and moral quality. Their appearance in negative news means that Chinese education should be improved. Meanwhile, some netizens realize the harmfulness of network violence, such as the behavior of "human flesh search" and introspect civil quality.

\section{B. The Collocation Analysis on "教授" ("Professors") in Corpus}

With the aid of the software of AntConc3.4.3., collocate tables of "教授"("Professors") ranked in top 28 according to their strength of collocation. The results are showed in Table II.

TABLE II

THE COLLOCATE TABLES OF "教授"("PROFESSORS") RANKED IN TOP 28 IN CORPUS

\begin{tabular}{|l|l|l|l|l|l|}
\hline Rank & Collocate & Stat & Rank & Collocate & Stat \\
\hline 1 & 局长(director) & 8.29 & 15 & 应该(should) & 4.89 \\
\hline 2 & 堂堂(dignified) & 8.29 & 16 & 叫兽(Jiaoshou) & 4.83 \\
\hline 3 & 名校(prestigious school) & 8.29 & 17 & 文化(culture) & 4.79 \\
\hline 4 & 滚出(get out) & 7.7 & 18 & 复旦(Fudan) & 4.78 \\
\hline 5 & 校长(principal) & 7.55 & 19 & 通奸(adultery) & 4.59 \\
\hline 6 & 历史系(Department of History) & 6.55 & 20 & 中国(China) & 4.59 \\
\hline 7 & 学生(students) & 6.38 & 21 & 哺乳期(breastfeeding period) & 4.53 \\
\hline 8 & 证据(evidence) & 6.29 & 22 & [doge] & 4.38 \\
\hline 9 & 教育(education) & 5.96 & 23 & 妻子(wife) & 4.23 \\
\hline 10 & 借口(excuse) & 5.7 & 24 & 怕(fear) & 4.2 \\
\hline 11 & 哈哈(haha) & 5.22 & 25 & 徐冲(Xu Chong) & 4.12 \\
\hline 12 & 大学(university) & 5.14 & 26 & 老师(teacher) & 4.06 \\
\hline 13 & 流讯(ruffian) & 4.93 & 27 & 渣(scumbag) & 3.16 \\
\hline 14 & 论文(paper) & 4.92 & 28 & 出轨(commit the infidelity) & 3.16 \\
\hline
\end{tabular}

As the data in Table II, the collocation in corpus can be divided into three categories: (1) the words related to behavior(adultery; fear; commit the infidelity) (2) the words related to netizens' attitudes to Xu (get out; should; 
dignified; excuse; haha; ruffian; Jiaoshou; [doge]; scumbag); (3) the words related to the theme (the words inside the event: Department of History; evidence; paper; Fudan; breastfeeding period; wife; Xu Chong; the words outside the event: director; prestigious school; principal; education; university; culture; China ; students; teacher).

First, for the words related to behavior, it can be seen that the behavior in this event is recognized as a betrayal to the marriage; meanwhile, the collocate of "fear" expresses the psychological activity of this vice professor. Second, for the words related to netizens' attitudes to $\mathrm{Xu}$, it shows netizens' obvious attitude to $\mathrm{Xu}$ as a professor in Chinese prestigious universities; all these attitude words illustrates that Xu's behavior seriously violates the conduct standard as a teacher and a professor, and most of netizens call him "Jiaoshou", "ruffian", " scumbag"; besides, some of netizens hold sardonic attitudes, such as "haha" and "[doge] (a emoji ( ( $\left.{ }^{+}\right)$in web chat meaning speechless and jeer)". Third, for the words related to the theme, it reveals that in the comments netizens not only criticise $\mathrm{Xu}$, but also some social groups in Chinese society who make publics disappointed because their incorrect conducts violate occupational criterions, such as "director" and "principal"; what's more, "education", "university", "China", "teacher" shows that through this events netizens even have a negative attitude to Chinese higher education.

All above the data shows that publics have a critical attitude to $\mathrm{Xu}$. As the college teacher with the highest academic title and official rank, professors represent the conscience and hope in society. Professors' improper behavior will result in the drop of their influence in publics. As for this case, it is a family dispute and personal affair, however it attracts wide attention from numerous netizens. The result of such behavior is only a joke offered for the netizens to have a gossip at their leisure time, and has no advantage to relieve the rigid relationship among parties.

\section{The Analysis of Concordance of "教授" ("Professor")}

The concordance lines related to the attitudes and the comments of "教授"("professor") posted by netizens are made through the software of AntConc3.4.3.

TABLE III

THE CONCORDANCE LINES ON THE ATTITUDE AND THE COMMENTS OF "教授"("PROFESSORS") POSTED BY NETIZENS

\begin{tabular}{|c|c|c|c|}
\hline 1 & $\begin{array}{l}\text { 这种人真是够了！陶喆做 ppt } \\
\text { (He is enough! Tao Zhe made a ppt }\end{array}$ & $\begin{array}{l}\text { 教授 } \\
\text { Professor }\end{array}$ & $\begin{array}{l}\text { 会写论文, 可以在一起弄个交流会了 } \\
\text { can write a paper. They can have a communication } \\
\text { meeting.) }\end{array}$ \\
\hline 2 & $\begin{array}{l}\text { 不管怎么样, 一个堂堂名校 } \\
\text { (No matter how the situation is, a }\end{array}$ & $\begin{array}{l}\text { 教授 } \\
\text { Professor }\end{array}$ & $\begin{array}{l}\text { 和小三一起动手打老人这点就够人大跌眼镜 } \\
\text { in prestigious universities hitting elders is too } \\
\text { surprising.) }\end{array}$ \\
\hline 3 & $\begin{array}{l}\text { 怎么教育好学生。还北大毕业, 复旦 } \\
\text { (How this kind of person can educate students well, } \\
\text { although he graduates from Peking University. }\end{array}$ & $\begin{array}{l}\text { 教授 } \\
\text { Professor }\end{array}$ & $\begin{array}{l}\text { 中国教育的耻辱, 中国教育的笑话 } \\
\text { in Fudan University is the humiliation and the joke of } \\
\text { Chinese education. ) }\end{array}$ \\
\hline 4 & $\begin{array}{l}\text { 不管怎样错就是错了, 还这么多借口, 如此 } \\
\text { (No matter what excuse he has, he is wrong and } \\
\text { shouldn't seek excuse for himself. Such a }\end{array}$ & $\begin{array}{l}\text { 教授 } \\
\text { Professor }\end{array}$ & $\begin{array}{l}\text { 能教出什么样的学生? 复旦真的完了! } \\
\text { Couldn't educate excellent students. Fudan is really } \\
\text { game over! ) }\end{array}$ \\
\hline 5 & $\begin{array}{l}\text { 就是这个畜生 } \\
\text { ( He is a beast }\end{array}$ & $\begin{array}{l}\text { 教授 } \\
\text { Professor }\end{array}$ & $\begin{array}{l}\text { [微笑]不配当一个老师, 最基本的师德都没有 } \\
\text { [smile] cannot be a qualified teacher, because he } \\
\text { doesn't have the basic teacher's ethic. ) }\end{array}$ \\
\hline 6 & $\begin{array}{l}\text { 这种人渣还 } \\
\text { ( Such kind of scumbag is }\end{array}$ & $\begin{array}{l}\text { 教授 } \\
\text { Professor }\end{array}$ & $\begin{array}{l}\text { 呢, 去死吧, 别带坏了学生 } \\
\text { Go to hell. Do not mislead students.) }\end{array}$ \\
\hline 7 & $\begin{array}{l}\text { 在外面出轨也找这借口? 这个 } \\
\text { How can he seek excuse for his infid-elity? This }\end{array}$ & $\begin{array}{l}\text { 教授 } \\
\text { Professor }\end{array}$ & $\begin{array}{l}\text { 简直可以用禽兽来形容 } \\
\text { can be compared with beast. }\end{array}$ \\
\hline
\end{tabular}

In Table III, it shows netizens' negative attitude to Xu. For example, netizens use "beast", "scumbag" to refer to Xu. $\mathrm{He}$ is "the humiliation and the joke of Chinese education" so he "couldn't educate excellent students". Among these words, "beast" in Chinese culture refers to the six kinds of animals, that is, cow, horse, sheep, chook, dog, pig, which can be used to refer to the terrible person. Here, netizens denounce Xu's infidelity with abusive derogatory term. However, such comments also have the tendency of language violence. Additionally, in the comments of Weibo, the emoji in a piece of comment is consistent with the attitude in it, which is always respond to the surface meaning in the information. Netizens use emoji, like "smile" ( $)$, "doge" $\left({ }^{+}\right)$, etc. to express the sneer and indignant attitude to Xu's behavior. Netizens deliver their emotion directly to people through these emoji with visualized characteristics. As a result, such action has an immediate influence to the whole atmosphere of the opinion field, which is consistent with the characteristic of Weibo that can be a platform to express personal feeling and emotion.

\section{CONCLUSIONS}

The comments in Weibo platform reflect netizens' emotion and ideology, and it also has the function of constructing professors' academic and moral image. But these data are not systematic and cannot be used as research data. However, with the interaction of corpus and computer software, it can combine qualitative and quantitative analysis to solve this problem. High-frequency word list, collocates, as well as concordances related to the key information all can work with critical discourse studies to analyze the texts and discourses. As a result, the researcher can discover the social problems 
underlying the language use. The research suggests that: (1) In Weibo, the new media, network catchwords are growing popular and tucao (revealing the inside story) is full of violence; (2) Although most of the netizens hold decent ethics and values, they go emotional easily. When commenting on the infidelity of the vice professor Xu, a vast majority of netizens choose to use languages filled with violence to express their negative attitude. (3) A series of negative cases in the media have already made "professor", a profession with relatively high social status, have a negative connotation. Professors should be perfect models of academics and moral quality. However, some of them with high academic level lacking ethics make the public disappointed. In conclusion, we suggest that netizens should consider issues rationally and make their speech acts normative; professors should reestablish their social images by enhancing academic and scientific research capability.

\section{ACKNOWLEDGEMENTS}

This work was supported by the National Social Sciences Fund Program "Critical discourse analyses of the cyber language violence" under Grant 15BYY057.

\section{REFERENCES}

[1] Baker, P. (2006). Using Corpora in Discourse Analysis. London: Continuum.

[2] Baker, P. \& Levon, E. (2015). Picking the right cherries? A comparison of corpus-based and qualitative analyses of news articles about masculinity. Discourse \& Communication, 2: 221-236.

[3] Ban, J. W. (2007). The Influences and Reasons of Teachers' Moral Images in Media and Its Betterment. Teacher Education Research, 6: 28-32.

[4] Blommaert J \& Bulcaen C. (2000). Critical discourse analysis. Annual Reviews of Anthropology, 20: 447-466.

[5] Blommaert J. (2005). Discourse: Key topics in sociolinguistics. Cambridge: Cambridge University Press.

[6] Fairclough, N. (1992). Discourse and Social Change. Cambridge: Polity Press.

[7] Fairclough, N. \& Wodak, R. (1997). Critical Discourse Analysis. In T.A. van Dijk (ed.), Discourse as Social Interaction. London: Sage, 258-284.

[8] Fairclough, N. (2009). A dialectal-relational approach to critical discourse analysis in social research. In Wodak, R. \& Meyer, M. (eds.), Methods of Critical Discourse Analysis. London: Sage, 162-186.

[9] Khosravinik M. (2014). Why discourse matters: Negotiating identity in the mediatized world. New York: Peter Lang.

[10] McEnery, T. \& Wilson, A. (2001). Corpus Linguistics: An Introduction. Edinburgh: Edinburgh University Press.

[11] Wang, Y. (2007). The Stereotypes in Representation Changes, Mass Communication, and Rewriting. Modern Communication(Journal of Communication University of China), 3: 125-127.

[12] Wen, L. L. \& Xu, J. F. (2014). An Concept Analysis of University Teachers' Professional Identity. Education Review, 10: 4548.

[13] Wodak R. (2011). Critical linguistics and critical discourse analysis. In Zienkowski J., J-O Östman, Verschueren J. (eds.) Discursive Pragmatics. Amsterdam: Benjamins, 50-65.

Weiwei Mao is now studying in Dalian University of Technology as a master candidate. Her research focus is social linguistics. 